\title{
Fair Equality of Opportunity Critically Reexamined: The Family and the Sustainability of Health Care Systems*
}

\author{
H. TRISTRAM ENGELHARDT, JR. \\ Rice University, Houston, Texas, USA. \\ Address correspondence to: H. Tristram Engelhardt, Jr., MD, PhD, Rice University, MS 14, \\ P.O. Box 1892, Houston, TX, 77251-1892, USA. E-mail: htengelh@rice.edu
}

A complex interaction of ideological, financial, social, and moral factors makes the financial sustainability of health care systems a challenge across the world. One difficulty is that some of the moral commitments of some health care systems collide with reality. In particular, commitments to equality in access to bealth care and to fair equality of opportunity undergird an unachievable promise, namely, to provide all with the best of basic health care. In addition, commitments to fair equality of opportunity are in tension with the existence of families, because families are aimed at advantaging their own members in preference to others. Because the social-democratic state is committed to fair equality of opportunity, it offers a web of publicly funded entitlements that make it easier for persons to exit the family and to have children outside of marriage. In the United States, in 2008, 41\% of children were born outside of wedlock, whereas, in 1940, the percentage was only 3.8\%, and in 1960, 5\%, with the further consequence that the social and financial capital generated through families, which aids in supporting health care in families, is diminished. In order to explore the challenge of creating a sustainable health care system that also supports the traditional family, the claims made for fair equality of opportunity in health care are critically reconsidered. This is done by engaging the expository device of John Rawls's original position, but with a thin theory of the good that is substantively different from that of Rawls, one that supports a health care system built around significant copayments, financial counseling, and compulsory savings, with a special focus on enhancing the financial and social capital of the family. This radical recasting of Rawls, which draws inspiration from Singapore, is undertaken as a heuristic to aid in

(C) The Author 2012. Published by Oxford University Press, on behalf of the Journal of Medicine and Philosophy Inc. All rights reserved. For permissions, please e-mail: journals.permissions@oup.com 
articulating an approach to bealth care allocation that can lead past the difficulties of social-democratic policy.

Keywords: fair equality of opportunity, family stability, bealth care financing, bealth care savings accounts

\section{THE SOCIAL-DEMOCRATIC WELFARE STATE: SIGNS OF A CRISIS}

The funding of health care is, in different ways, a challenge across the globe. Everyone wants the best of care, although not all want to pay for it. Moreover, current forms of health care financing in North America and Western Europe may not be financially sustainable. Citizens have been promised equal access to the best of basic health care, which may be unaffordable for many polities and is in fact impossible to provide. Given limitations of expertise, the best of basic medical care cannot be provided to all. For example, everyone cannot have access to those few surgeons who are most skilled in resecting abdominal aortic aneurysms, but most must instead make do with those who have less than the very best expertise, with consequent, concomitant greater morbidity and mortality risks. These challenges, rooted in the finitude of financial resources and expertise, are compounded by wide-ranging changes in the dominant secular culture of the West, which further challenge the sustainability of social-democratic approaches to the provision of health care. Among other things, there are the difficulties associated with the erosion of the traditional family and the loss of its social capital. In these reflections, a social-democratic polity is stipulatively understood as a polity that conforms in its constitutional framework and system of laws to the requirements outlined by Rawls in his two principles of justice (Rawls, 1971, 302). A socialdemocratic state will therefore be committed to the most extensive total system of equal basic liberties, with offices and positions open to all under conditions of fair equality of opportunity, and where social and economic inequalities are accepted only insofar as they are to the greatest benefit of the least advantaged. These concerns with equality and equality of opportunity form a major focus of this essay.

In the reflections that follow, basic health care identifies all health care that has been shown to be effective to a more-than-minimal extent in lowering the risk of early death and/or diminishing, relieving, or at least ameliorating major forms of pain and suffering through addressing anatomical (including genetic), physiological, and psychological states of affairs that are beyond the immediate willful control of the patient or others. For the purposes of this essay, medical interventions that have not been established as effective are not considered basic medical or health care, although no particular criteria are presupposed for the establishment of an intervention as effective. Basic health care when delivered with an enhanced quality that more than minimally diminishes mortality risks and/or morbidity is termed better 
basic health care. Examples of better basic health care would be treatment of a malady by a physician whose expertise is clearly better than average or access to expensive pharmaceutical or medical devices that more than minimally decrease mortality and/or morbidity and that are not provided by a polity's guaranteed health care entitlements to basic health care. Being able to avoid a queue for services when a delay of treatment would generally produce a more-than-minimal increase in morbidity and/or mortality risks would also constitute access to better basic health care. What should exactly count as "minimal" is not explored.

The focus of this essay is on rethinking the norms that should guide health care allocation. The reconsideration of the normative concerns that frame health care policy has urgency, given the financial difficulties besetting many Western social-democratic states. Across the developed world, with few exceptions, health care consumes an ever larger percentage of the gross domestic product, raising issues about financial sustainability. In Western Europe, health care expenditures contribute to the financial crises of social-democratic polities. Undoubtedly, the current financial crises besetting Western Europe and North America were precipitated by various problems in debt markets that were not directly related to the social welfare state. However, the financial crises have deep roots in the extensive state support of a wide range of entitlements that now constitute a major portion of the budgets of Western European and North American states. For example, entitlements constituted $62 \%$ of the 2010 US federal budget, $20 \%$ was committed to social security payments, $21 \%$ to Medicare and Medicaid, $7 \%$ to benefits for federal retirees and veterans, and 14\% to unemployment and other welfare entitlements (Center on Budget and Policy Priorities, 2011). The result is that government budgets cannot easily be cut back in response to fiscal crises, given commitments to entitlements, including commitments to the governmental support of health care.

There is urgency as well to address a concomitant phenomenon: the erosion of the traditional family and the resultant poverty associated with families headed by single women. Not only does the erosion of the family generate social costs, in the case of health care, it diminishes the social resources of traditional families to provide informal nursing and other care. "Traditional family" is used here to identify a married man and woman who are the parents of the family's children. In response to problems of financial unsustainability and to the erosion of the family, the creation of family-oriented health care savings accounts is considered in order not only to diminish the contribution of moral, demographic, and political hazards to financial unsustainability of health care systems but also to maintain traditional families. This recommendation is forwarded through the articulation of an approach to health care allocation grounded in a non-Rawlsian vision of justice.

Drawing inspiration from Singapore, a proposal that would allow one to address both the problem of the financial sustainability of health care systems 
and the erosion of the traditional family is advanced. This is undertaken through a reconstruction of the normative presuppositions that frame Singaporean public policy in these areas. For the purpose of this article, Singapore is understood to be committed to aiding its citizens in becoming responsible participants in their health care decisions through mandatory copayments, financial counseling prior to hospital admission, the accumulation of capital in a health care savings account (i.e., Medisave), and the maintenance of the family. Singapore paternalistically requires its citizens to save, encourages an internal locus of responsibility, and nurtures the ethos that there is no free lunch. Singaporeans, depending on their earnings, must save approximately $36 \%$ of their gross salaries, about half of which comes from employers. Singapore's compulsory savings policy, and the Central Provident Fund it created, is focused on enhancing self-reliance. The Central Provident Fund is divided into an Ordinary Account, from which one may purchase housing, buy insurance, pay for education, and invest to increase capital, a Special Account for retirement, and the Medisave Account. The total assets of the Central Provident Fund in 2011 were S\$208 billion (Singapore Central Provident Fund, 2012, 23). Given the background Confucian ethos of Singapore (Fan, 2010, 2011) and the circumstance that funds accumulated can be transferred, without tax consequences, to family members, the system also favors the maintenance of the traditional family.

Singapore's success is somewhat remarkable. In the year 1965, 50\% of health care costs in Singapore were supported by the government; by 2000, this had fallen to $25 \%$, with health care costs constituting $4.5 \%$ of the gross domestic product of Singapore (Cheah, 2010). The health outcomes from Singapore's system are quite impressive, with a perinatal mortality rate of 2.2 per 1000 births (Lim, 2004, 90) and a life expectancy, in 2010, of 79.3 years for men and 84.1 years for women (Ministry of Health, 2012). The Singaporean public/private partnership in health care financing is built around its Medisave program (the funds, 6\%-9\% from wages, are earmarked primarily for costs associated with hospitalization). In addition, there is the Medishield program (which is a low-cost catastrophic illness insurance, the premiums for which can be paid for out of Medisave, as can the premiums of private insurance that offers a Medisave-approved Integrated Shield Plan; Joshi and Lim, 2010), as well as Eldershield, a severe-disability insurance for the elderly that can as well be paid out of Medisave funds. Finally, there is the Medifund program, a means-tested public safety net of last resort, and an Eldercare fund that subsidizes voluntary welfare organizations caring for the elderly. One should note that Medisave covers only $8 \%$ of health care costs, with another 2\% being paid by Medishield and Medifund; 35\% of health care costs in Singapore are paid by employers, 25\% are out of the individual's pocket, $5 \%$ are paid by private insurance, with $25 \%$ being paid for by the government (Lim, 2004, 86). Government funds are expended in subsidizing public hospitals and hospital care for those of more limited resources who would opt for more spartan care. The private sector accounts for $80 \%$ of primary care but only 20\% of tertiary care (Sanyal et al., 2008, 4). 
To enhance responsible choices, there is financial counseling as a part of hospital admission in order to help patients and their families to choose an appropriate level of treatment. Class A treatment in a public hospital, for example, includes a bed in an air-conditioned two-bed room with attached bathroom, television, telephone, and choice of physician, but without subsidy, and Class C treatment enjoys an 80\% subsidy, in which case, the patient stays in an open, unair-conditioned ward with eight or more beds, and without choice of physician. Because government subsidies are paid directly to hospitals, although only $10 \%$ of total health care costs are paid by Medisave, Medishield, and Medifund, for most Singaporeans these constitute a substantial portion of their actual payments for hospital care. The result is a health care ethos that is not structured by a commitment to fair equality of opportunity, and instead incorporates a nonegalitarian altruism. This study explores how this approach to health care allocation by eschewing a commitment to fair equality of opportunity can maintain financial sustainability and, in addition, check the erosion of traditional family structures.

This essay argues that the Rawlsian endorsement of fair equality of opportunity should be rejected, not only because the goal cannot be coherently realized, but more fundamentally because the concern for fair equality of opportunity crowds out moral commitments to altruism. Pursuing equality for equality's sake diverts attention from the importance of focusing on ameliorating the suffering of those who have less of some important good or service. Rawls's expository device of the original position is engaged to lay out the geography of an alternative approach to the allocation of resources for health care through incorporating a different thin theory of the good so as to explore how to meet the financial and social crises threatening the financial sustainability of health care systems in Europe and North America. A thin theory of the good is articulated, which abandons Rawls's emphasis on equality of opportunity. Instead, while recognizing the importance of the pursuit of prosperity, this alternative thin theory of the good affirms a nonegalitarian altruism and acknowledges the central social embeddedness of humans in families. In the light of this normative vision, one can better appreciate the attractiveness of compulsory savings over taxation for the support of health care, as well as the necessity of avoiding Rawls's hermeneutic of suspicion with regard to the family, which suspicion is a direct result of his commitment to fair equality of opportunity.

\section{CRITICALLY RECONSIDERING AN ILLUSION}

The social-democratic welfare systems of the West have engendered a financial challenge in which more has often been promised for pensions and health care than the available resources can support. The difficulties are in great measure rooted in a failure to face honestly the constraints imposed by human finitude, human passions, and personal freedom on the egalitarian 
aspirations of social-democratic public policy. Because most humans are interested in living longer, if this is possible, without significant morbidities, there are insufficient resources for health care systems that promise the best of basic health care to all. The core difficulty is human finitude itself. All humans will die, and most will suffer before they die. Given the finitude of human resources as well as limited human expertise, and given human freedom, even in the most affluent societies, all cannot receive the best of basic health care. It is impossible, given the limitation of financial resources and expertise (e.g., the highest of surgical skills for the resection of abdominal aortic aneurysms), to give the best of basic health care equally to all.

In all social insurance and similar entitlement-based approaches to the allocation of health-based resources, there is a moral hazard in that, once an entitlement is established, it will tend to be exploited to its utmost. In addition, if a health care system depends on taxing those who are well and working to pay for those who are sick and/or not working, the system will face a demographic catastrophe if there is a significant decline in the percentage of the working well. The striking decrease in reproductive rates among Western Europeans and North Americans has been tied both to the effects of their welfare systems as well as to the emergence of an antinatal ethos in which it is no longer taken for granted that men and women will marry and have children. ${ }^{1}$ The result has been insufficient resources for (i.e., insufficient payers to support) generous pensions with early retirements, as well as for ample publicly supported health care systems. Last, but surely not least, socially financed health care systems involve a political hazard, in that politicians have an incentive to promise better and more encompassing health care benefits in order to advance their political careers, even if the available resources are insufficient to pay for those benefits. These factors have combined to raise questions regarding the financial sustainability of social-democratic welfare systems, as well as to make it difficult to achieve anything like equality in access to the best of basic health care. As the quality of the general health care system deteriorates, the more there is an incentive to find access to better basic health care, making the achievement of equality of access impossible.

Freedom is incompatible with equality. Humans make bargains and enter into projects that lead to the relative advantage of those with financial and/or social resources. In particular, humans tend to use their money and personal influence to gain access to better basic health care for themselves and for those to whom they are most closely bound. As a result, the institution most corrosive of equality of outcome, as well as of equality of opportunity, is the traditional family. The traditional family tends to be more committed to supporting its members rather than others. In addition, the traditional family has social capital on which it can draw in providing informal nursing and other support to its own members. Although the traditional family enjoys all of these advantages, the traditional family in the West is in the process of being 
eroded and marginalized due to the character of the support and welfare offered by social-democratic states.

In part, the erosion of the traditional family follows from well-meaning welfare and other support offered to unmarried women, which has had the side effect of encouraging some to reproduce and raise children outside of a traditional family structure. Beginning in the 1960s, the United States directed energies to eliminating poverty through President Lyndon Johnson's War on Poverty. However, governmental welfare policy undermined the family in making reproduction without marriage financially attractive (Moynihan, 1965), leading to the emergence of an ethos that encouraged reproduction outside of a traditional marriage and led to further poverty (Edin and Kefalas, 2005). ${ }^{2}$ Considerable evidence exists to show that the structure of many welfare programs is such that they encourage women to have children outside of marriage (this is particularly the case with Aid to Families with Dependent Children). ${ }^{3}$ Francis Fukuyama provides an overview of this political and social history:

Moynihan's critique was extended by Charles Murray, who pointed to the unanticipated consequences of welfare programs like Aid to Families with Dependent Children (AFDC), which encouraged out-of-wedlock births and contributed to the culture of poverty. This critique of AFDC led ultimately to its abolition under the Personal Responsibility and Work Opportunity Reconciliation Act of 1996, initiated by the Republican Congress and signed by President Bill Clinton (Fukuyama, 2006, 20).

There appears to be a strong connection between the presence of the support and welfare web of social-democratic states and the decline of the traditional family. ${ }^{4}$ The emergence of families headed by single mothers is in most cases strongly associated with fewer resources, including health care resources, available for such families (Rector, 2010). This erosion of the family, although lamented by many, is celebrated by those who recognize that the traditional family substantively undermines equality of opportunity, while additionally supporting traditional, patriarchal, and heterosexist ideals and relationships. ${ }^{5}$

In the West, the decline of the traditional family has been dramatic. In little more than half a century, there has been a substantive increase in the number of children born outside of traditional marriage. The rate of out-of-wedlock births was probably at 4\% through most of American history and was such in 1950. The percentage had risen to 10\% in the United States in 1970 and 18\% in 1980. The rate in the United Kingdom for 1980 was 11.5\%. By 2000 , the number of children born outside of a traditional marriage had risen to $33.2 \%$ in the United States and 39.5\% in the United Kingdom (Thévenon, 2010, 58-59). Nine years later, in 2009, the rate was $41 \%$ in the United States and $46.3 \%$ in the United Kingdom. There are significant differences tied to race in the United States; 36\% of whites, 53.2\% of Hispanics, and $72.3 \%$ of blacks were born outside of traditional marriage in 2009; among Asians, only 17.2\% were born outside of traditional marriage (Martin et al., 2011, 46). 
The number of children in Singapore born outside of marriage, one should note, is so low as simply to be described as "negligible" (Saw, 2005, 128). These changes are complex, but, in general, when combined with the birth of fewer children, they contribute to the social and economic burdens of social-democratic states. ${ }^{6}$

\section{JUSTICE AS A POLITICAL PROJECT}

John Rawls's $A$ Theory of Justice has had a major influence on reflections concerning the proper structure for health care allocation. This is the case despite the fact that Rawls himself never addressed the issue of health care. Rawls may in fact have avoided addressing justice in health care, because he recognized that issues of health care would have disclosed central difficulties with his account of justice. A particular difficulty that health care poses is that many losses at the natural lottery, such as early death and severe irremediable disabilities, cannot be made whole. The losses are of a character such that no social response can return the person affected to a state on a par with that of others. In contrast, with respect to other losses, persons can be compensated and often made whole. One can even craft policy that renders humans equal in terms of financial and social resources. However, such is impossible in the case of losses with regard to health status. Equality in health status cannot be achieved for all humans. Nor can health care provide equality of opportunity for those who die young or have very severe disabilities.

Rawls engaged the expository device of the original position to bring people to affirm a social-democratic approach to social issues. Through his expository device of the original position, Rawls invited one to consider how one would establish a society so that one would accept one's position in that society as fair, not knowing in advance what one's social and financial position would be. The choices of Rawls's fictive contractors are framed by a background commitment to having social and financial resources divided equally, unless an unequal division would increase everyone's share, and in which no risk is taken to augment one's share. To establish the general lineaments of their society, these hypothetical contractors must have at least a thin theory of the good and an understanding of appropriate decision making. The particular thin theory of the good which Rawls supplied his hypothetical contractors with ranks liberty first, then fair equality of opportunity, and then concerns for social and financial resources. This thin theory of the good is reflected in Rawls's two principles:

First Principle

Each person is to have an equal right to the most extensive total system of equal basic liberties compatible with a similar system of liberty for all. 


\section{Second Principle}

Social and economic inequalities are to be arranged so that they are both:

(a) to the greatest benefit of the least advantaged, consistent with the just savings principle, and

(b) attached to offices and positions open to all under conditions of fair equality of opportunity (Rawls, 1971, 302).

In addition, Rawls constructed his contractors so that they lack envy in order to allow his contractors to accept inequalities that arise within the constraints set by his First Principle and the requirements of fair equality of opportunity, as long as those inequalities also redound to the benefit of the least-well-off class.

If one embraced this portrayal of hypothetical decision makers, of contractors in the original position, and attempts to apply it to health care, then at the most, the contractors would allow inequalities in access to health care only if these inequalities redounded to the benefit of the least-well-off, because they, the contractors, might find themselves in the worst-off class. However, if the least-well-off were those who die early, this would require a massive transfer of health care resources to research and treatment in order to ensure that children did not die young but could reach at least an average lifespan. Geriatric research and treatment would be bypassed in favor of particular areas of pediatric research and treatment. That is, one would, as an original contractor, require that resources be used to address the plight of the least-well-off class in health status so as to respond to the risk that one would be a member of the class of such disadvantaged persons. One can only escape these difficulties through ad hoc alterations in the moral rationality that is to guide the hypothetical contractors (Daniels, 1985).

Even as he wrote $A$ Theory of Justice, Rawls recognized that his account was dependent on a particular thin theory of the good and a particular view of rational moral decision making, which account he could not establish as canonical through sound rational argument. Rawls appreciated the contingency of his point of departure and of the moral vision he addressed. For example, Rawls stated:

For while some moral principles may seem natural and even obvious, there are great obstacles to maintaining that they are necessarily true, or even to explaining what is meant by this. Indeed, I have held that these principles are contingent in the sense that they are chosen in the original position in the light of general facts. More likely candidates for necessary moral truths are the conditions imposed on the adoption of principles; but actually it seems best to regard these conditions simply as reasonable stipulations to be assessed eventually by the whole theory to which they belong. There is no set of conditions or first principles that can be plausibly claimed to be necessary or definitive of morality and thereby especially suited to carry the burden of justification (Rawls, 1971, $\mathbb{1 8 7}, 578$ ). 
It may be said that the agreement in considered convictions is constantly changing and varies between one society, or part thereof, and another (Rawls, 1971, §87, 580).

Because Rawls acknowledged that he was not able to give a universal moral account, an account offering a moral view of justice sub specie aeternitatis, he had to advance his account in other terms.

Fourteen years after $A$ Theory of Justice, Rawls even more frankly admitted that he could not give a context-free account of justice as fairness, or for that matter, even a necessary and universal moral account. He explicitly stated that he wished to avoid "claims to universal truth, or claims about the essential nature and identity of persons" (Rawls, 1985, 223). Instead, Rawls acknowledged that he was advancing a particular approach to political structures, recognizing that his basic moral intuitions "drawn upon in justice as fairness are combined into a political conception of justice for a constitutional democracy" (Rawls, 1985, 223). What had been taken by many to be a moral account of justice is instead to be accepted as a political account of justice that advances particular socio-democratic views, which Rawls characterized as "political liberalism." As Rawls put it, "political liberalism looks for a political conception of justice that we hope can gain the support of an overlapping consensus of reasonable religious, philosophical, and moral doctrines in a society regulated by it" (Rawls, 1993, 10). The theory of justice must be understood in terms of its place within a political project.

Rawls took the political turn in order more plausibly to relocate his normative claims within a political vision, a social-democratic constitutional agenda, to be precise. He did this because he, like Hegel (1770-1831), Richard Rorty (1931-2007), Gianni Vattimo (1936-), and others, recognized that one cannot establish a canonical morality through sound rational argument. Such a foundational project would require the equivalent of a God's-eye perspective that could disclose or at least endorse a particular content-full view that was not the result of sociohistorical contingencies, but rather reflected the cosmic order, the deep structure of being, or the will of God (Engelhardt, 1996, Chs. 1-2). Because such a grounding cannot be presupposed in a postmodern secular culture, any particular affirmation of a particular thin theory of the good lacks a conclusive necessity. If one approaches reality in the light of an agnostic postulate, then all is regarded as coming from nowhere, going nowhere, and for no ultimate purpose. By confronting this state of affairs, Rawls realized that his lexical ordering of liberty, equality, and the possession of social and economic goods that constitutes the substance of his thin theory of the good lacks a universal moral standing or necessity. No such content-full view of morality and/or justice could be established as canonical without begging the question, arguing in a circle, or engaging an infinite regress. It was for this reason that Rawls relocated his claims within a political program that reflected his moral intuitions, a program he held was likely to carry the day. 
We suppose also that these ideas can be elaborated into a political conception of justice that can gain the support of an overlapping consensus. Such a consensus consists of all the reasonable opposing religious, philosophical, and moral doctrines likely to persist over generations and to gain a sizable body of adherents in a more or less just constitutional regime, a regime in which the criterion of justice is that political conception itself. Whether justice as fairness (or some similar view) can gain the support of an overlapping consensus so defined is a speculative question. One can reach an educated conjecture only by working it out and exhibiting the way it might be supported (Rawls, 1993, 15).

Rawls continued to advance his moral intuitions, but now located within a political narrative that gained objectivity through the supposition that it will be vindicated by history.

Rawls's clear statements on the matter notwithstanding, many of the students and followers continued to read him as having offered a moral account of justice. They then proceeded to apply Rawls's account of justice as fairness to health care allocation. The most influential of these applications of a Rawlsian theory of justice to health care was developed by Norman Daniels (Daniels, 1985, 1996, 2008; Daniels \& Sabin 2002). Those who wanted to apply Rawls's account of justice to health care recognized that they needed to determine whether the provision of health care was like the protection of civil liberties, that is, whether it was tied to protecting liberty, which was Rawls's first social goal (Green, 1976), or instead whether the provision of health care is best understood as integral to the pursuit of fair equality of opportunity, or in fact whether access to health care is more like access to social and economic goods that, according to orthodox Rawlsians, may be distributed unequally if this unequal distribution redounds to the benefit of the least-well-off. Daniels for his part located the support of health care with the support of fair equality of opportunity (Daniels, 1981). Others, however, recognizing the major moral, financial, and policy difficulties involved in attempting to ensure equality in access to health care or the realization of equality of opportunity through health care, placed health care within the difference principle, so that inequalities in access to health care would be morally acceptable if they redounded to the benefit of the least-well-off class (Stern, 1983). In the cases of regarding health care as integral to liberty as well as integral to the pursuit of fair equality of opportunity, the view taken was that, just as social-democratic states should not tolerate inequalities in basic civil liberties or in fair equality of opportunity, equality in the provision of health care would need to be achieved. Stern's approach, in contrast, would allow inequalities.

A major difficulty remains: it is far from clear what it should mean to achieve the equality that liberty and equality of opportunity-based interpretations of Rawls would demand. The problem is that one cannot achieve equality in health because of the ways in which disease, disability, and early death render persons radically unequal. As already noted, would a 
commitment to equality require first and foremost spending as much as possible, as long as there was some amelioration of the suffering and disability, as well as some postponement of death among those most severely disabled or threatened by early death? It would seem that in a Rawlsian account, the focus should be on equality of result in these cases rather than on equality of access, because it is differences in health status that deprive such persons of equality of opportunity. However, because it is impossible to render all equal in terms of span of life, health, and freedom from morbidity, most of those who engage Rawls focus on the equality of input. They focus on assuring that none will receive better basic health care when most receive only basic health care. There is to be only one menu from which to order basic health care, so that one will be prohibited from acquiring better basic health care. The difficulty is that once one focuses on input, one will have abandoned the original ground for pursuing equality, namely, a concern with the circumscribed liberty and/or equality of opportunity of those who die young or who are radically disabled.

The focus on input (rather than on outputs of lowered morbidity and mortality, as with the Oregon Plan; Strosberg et al., 1992) also has the difficulty that it legitimates an egalitarianism of envy in which one is concerned about those who have access to better basic health care, even though (1) a focus on how one could as cheaply as possible decrease morbidity and mortality would be more useful, and even when (2) the circumstance that some would have access to better basic health care will not harm those receiving only basic health care and may indeed advantage the health status of the least-well-off (i.e., through bringing more capital into the health care system). When equality is pursued for equality's sake, law and public policy focus on preventing some from access to more and better health care, even if no one is harmed by having better basic health care. Also, once one moves the focus from output to input, one has embraced a genre of egalitarian concerns that is no longer focused on the plight of the least-well-off as such, but rather on equality as such. Once the focus is on equality as such, or for that matter equality of opportunity, one will also be distracted from asking the scientific question as to how one can as cheaply and efficiently as possible advantage those with limited lifespan and significant disability, even when this does not lead to an equality of outcome.

In stepping away from a moral account of justice as fairness to a political account, Rawls did not need explicitly to address these puzzles regarding health care allocation. This is not to claim that Rawls would not be committed to an egalitarian, one-tier health care system, somewhat as Canada once possessed. It is rather to note that how one shapes the character of such a system will be a matter guided by the politically reasonable, not the morally rational. One is brought then to the conclusion that Rawls himself recognized the particularity and contingency of his particular thin theory of the good (Rawls, 1971, \$60, 395-399) and, therefore, of his two principles 
of justice (Rawls, 1971, §46, 302-303), along with the difficulties of applying them to health care.

\section{THE FAMILY VERSUS FAIR EQUALITY OF OPPORTUNITY}

A cardinal tension remains to be examined. In constructing his account of justice, Rawls appealed to persons as members of families while also recognizing that a commitment to fair equality of opportunity brings the family itself into question. On the one hand, the hypothetical contractors, by thinking of themselves as heads of families, allowed Rawls to give a ground for them to be committed to the best interests of their descendants and thus to the just savings principle. He engaged with implicit approval the truth that families tend to be interested in their own future members.

[W] may think of the parties [in the contractual circumstance of the original position] as heads of families, and therefore as having a desire to further the welfare of their nearest descendants. As representatives of families their interests are opposed as the circumstances of justice imply. It is not necessary to think of the parties as heads of families, although I shall generally follow this interpretation. What is essential is that each person in the original position should care about the well-being of some of those in the next generation (Rawls, 1971, \$22, 128).

The family here plays for Rawls a positive role in terms of making intergenerational savings integral to justice as fairness.

However, Rawls clearly also appreciated that the very characteristic that makes the family essential to legitimate his intergenerational savings also makes the family the enemy of fair equality of opportunity. First, he possessed a moral suspicion regarding the traditional family, in that the traditional family is qua traditional family patriarchal. He also denied to families an area of privacy within which family members could consent to nonegalitarian relationships. "If the private sphere is alleged to be a space exempt from justice, then there is no such thing...the equal rights of women and the basic rights of their children as future citizens are inalienable and protect them wherever they are" (Rawls, 1997, 791). This view is articulated against the background of Rawls's sympathy with John Stuart Mill's criticism of the traditional Western family.

Mill held that the family in his day was a school for male despotism: it inculcated habits of thought and ways of feeling and conduct incompatible with democracy. If so, the principles of justice enjoining a reasonable constitutional democratic society can plainly be invoked to reform the family (Rawls, 1997, 790-91).

The traditional family for Rawls brings along baggage from the past that he held ought to be abandoned.

Second, and more fundamentally, as already noted, Rawls was critical of the family for the very reason that the family was useful in justifying 
intergenerational obligations. Because families are concerned with their own members, they advance the interests of their family in preference to the interests of others, thereby undermining fair equality of opportunity. Rawls therefore acknowledged that "the principle of fair opportunity can be only imperfectly carried out, at least as long as the institution of the family exists" (Rawls, 1971, \$12, 74). As to what to do about the family, Rawls waffled. He recognized that he had a basis to argue that the family ought to be abolished, yet he stepped back from actually calling for its abolition.

The consistent application of the principle of fair opportunity requires us to view persons independently from the influences of their social position. But how far should this tendency be carried? It seems that even when fair opportunity (as it has been defined) is satisfied, the family will lead to unequal chances between individuals. Is the family to be abolished then? Taken by itself and given a certain primacy, the idea of equal opportunity inclines in this direction. But within the context of the theory of justice as a whole, there is much less urgency to take this course (Rawls, 1971, \$77, 511).

Given his commitment to fair equality of opportunity, Rawls should have explicitly held that ceteris paribus, the family should be abolished.

Finally, Rawls's theory of justice is also implicitly aimed against the family, in that, save for the hypothetical contractors being concerned for their future generations, his contractors and actual citizens are conceived of as bare individuals whose liberty, equality, and prosperity are realized in individual terms. Their status is first as citizens, not as family members or members of other intermediate institutions. Rawls is importantly noncommunitarian in considering persons first and foremost as citizens of the state. No social structure has independent standing or authority between the individual and the state. The result is that a Rawlsian social welfare system, including its approach to health care, aims at aiding individuals apart from their location within families. In fact, the social welfare system in a Rawlsian polity, in order to support the flourishing of individuals, would be structured so as to enable persons to leave their families easily. It is not an accident that the modern social welfare state is highly associated with the contemporary erosion of the family.

\section{RECONCEIVING JUSTICE IN HEALTH CARE: SOME SINGAPOREAN REFLECTIONS}

As a cluster of moral intuitions held together as a freestanding moral narrative, Rawls's account of justice as fairness generates puzzles, collides with a major social institution (i.e., the family), and does not provide a basis for a financially sustainable health care system. Core to the difficulties is the commitment to fair equality of opportunity. One is then led to the question as to whether one can envisage a thin theory of the good that would be more 
promising to guide in erecting health care policy. To explore this possibility, this essay now turns to examining what it would mean to understand justice in health care, drawing on some Singaporean insights. This reconceiving of justice in health care involves laying out the normative underpinnings of the Singaporean approach to health care financing in order to better meet the financial challenges to the sustainability of health care systems, as well as to address the erosion of the family. What is offered should be understood as a particular possible reconstruction of the background thin theory of the good that underlies Singaporean health care policy as a heuristic for health care policy.

The claim is not to have reconstructed Singaporean health care policy in all its particularities. Instead, the goal is to have made explicit the cardinal commitments that have allowed Singapore to devise a financially sustainable approach to health care through which it has (1) provided good health care to its citizens at a remarkably low cost, (2) accumulated capital for Singaporeans and Singapore, (3) framed an approach to retirement, health care, and other needs of its citizens, while (4) not having eroded, and apparently even supported, the traditional family. An element essential to the Singaporean approach is that it does not pursue equality or equality of opportunity as an independent guiding norm or goal. Instead, goals such as a family-centered self-reliance and economic independence are given priority. In addition, the culture of Singapore, reflecting Confucian culture generally, acknowledges that the usual and biologically natural original locus of persons is the family (Fan, 1997).

One can better appreciate the background normative commitments of Singapore's view of justice as fairness if one recognizes that an original position that would function as an expository device to lay out the commitments of Singapore would populate its original position with hypothetical contractors, guided by a thin theory of the good quite different from that of Rawls. Their thin theory of the good would place the protection of personal life and property first, the security of families second, and the pursuit of prosperity (the increase of financial and other social resources) third, while also being guided by a nonegalitarian altruism, reflected in Medifund, that supports offering basic health care to the impecunious. In all of this, there would be no moral concern for equality or equality of opportunity as an independent moral goal. Very importantly, like Rawls's contractors, the Singaporean contractors in the original position would think of themselves as "as heads of families, and therefore as having a desire to further the welfare of their nearest descendants" (Rawls, 1971, \$22, 128). But very much unlike Rawls, there is no hermeneutic of suspicion regarding the family, because there is no affirmation of fair equality of opportunity. Therefore, the Singaporean hypothetical contractors can support the establishment of public policy, including health care savings accounts, in ways that can strengthen the integrity of the family. 
Given these background normative commitments, and given the generally poor track record of governments in preserving earmarked funds for pensions and the support of health care, the Singaporean reliance on compulsory savings rather than only taxation becomes a compelling policy choice. In the absence of egalitarian constraints, the fact that some will have saved more in their Medisave accounts than others is quite acceptable, as long as the system benefits those who participate and makes provision for the impecunious. Singaporean moral commitments allow law and public policy to avoid focusing on equality itself, and instead to direct energies guided by nonegalitarian altruism toward blunting harms associated with persons lacking important goods and services. It is the suffering associated with lacking crucial goods and services, not the inequality itself, that is the focus of moral concern.

Since its founding, Singapore has pursued security of life, property, and families, as well as the achievement of prosperity. Among the consequences is that property rights are more basic than civil rights. In addition, in the absence of an independent concern for equality or equality of opportunity, a nonegalitarian altruism toward others can be affirmed without making impossible promises (e.g., that all will have equal access to the best of basic health care) or warranting a hermeneutic of suspicion against the family. Among the various results of this nonegalitarian ethos is the accumulation of Medisave funds (only about one-sixth of which is expended per year for health care costs, the remaining being saved). ${ }^{7}$ This commitment to compulsory savings has helped to blunt the force of the moral, demographic, and political hazards that have challenged the health care systems of Western Europe and North America. In addition, the circumstance that in Singapore the funds acquired can be used for all family members helps to maintain the family as a significant intermediate social institution. It may very well be the case that in order to have health care savings accounts most effectively contribute to the maintenance of family structures, other provisions may need to be incorporated in order to transform health care savings accounts into effective family-oriented health care savings accounts. This may mean erecting financial penalties for divorce in Singapore, where the divorce rate in 2011 is still at the low level of 7.5\% (Department of Statistics Singapore, 2011). ${ }^{8}$

An important question remains: can one get to Singapore from either Western Europe or North America? Given the embeddedness of Western European and North American welfare and health care systems in social-democratic assumptions and commitments, can enough of Singapore be acquired by Western European and North American polities so as to secure greater financial sustainability and to check the erosion of the family? Depending on circumstances in other polities, were other polities to adopt this approach, it would be necessary to judge in terms of their own circumstances what amount of reliance on compelled savings will be sufficient in order to change the ethos of the health care system. Could Singapore's success be imported 
elsewhere? At bottom, this is an empirical, social-political question, which only real-life attempts can test. Any attempts to import the virtues of Singapore to other polities will require eschewing John Rawls's thin theory of the good and its commitment to fair equality of opportunity and instead embracing the Singaporean commitment to self-reliance, albeit through compulsory savings, its affirmation of the family, and its embrace of nonegalitarian altruism.

\section{NOTES}

* This paper has as a distant ancestor "Engelhardt (2012)," which was itself derived from a more distant ancestor, a presentation in Jinan, China, on December 9, 2011, "Health Care Financing: A Philosophical Reflection," Keynote Address, Healthcare Savings Accounts, Healthcare System Reforms, and Confucian Bioethics International Conference.

1. For a reflection on an antinatal reproductive ethos, which puts the burden of proof on those deciding to reproduce, see Overall (2012).

2. For an overview of some of the issues associated with the new reproductive ethos, see Rector (2010). For further reflections of these changes in reproductive ethos and their wide-ranging implications for the social-democratic welfare state, see Anzenbacher (2002), Baumgartner (2003), Blome (2009), Eid (1982), and Grandits (2010).

3. See Moynihan (1965) and Wilson (1988), as well as Cherry's (2011a) exploration of the ways in which private charity, in contrast to social welfare entitlements, tends to support the good of the family.

4. This is not to claim that families produce only benefits and no costs. Families impose costs on persons, just as do states. Those suspicious of the family note, for example, the amount of child and spouse abuse that occurs within families. However, the existence of some abuse does not itself justify setting the integrity of the family aside. Given the importance, one judges, that autonomy and integrity of the traditional family have, one will variously establish the onus probandi for intrusions into the family.

5. For an examination of the good associated with marriage and family, see Cherry (2011b).

6. There are data to indicate that children raised by single mothers, and even children raised by their biological but unmarried parents, have more difficulties and are therefore more likely to impose costs on society beyond the association between being a single mother and poverty (Rector, 2010). For example,

No matter what the outcome being examined - the quality of the mother-infant relationship, externalizing behavior in childhood (aggression, delinquency, and hyperactivity), delinquency in adolescence, criminality as adults, illness and injury in childhood, early mortality, sexual decision making in adolescence, school problems and dropping out, emotional health, or any other measure of how well or poorly children do in life - the family structure that produces the best outcomes for children, on average, are two biological parents who remain married. Divorced parents produce the next-best outcomes. Whether the parents remarry or remain single while the children are growing up makes little difference. Never-married women produce the worst outcomes. All of these statements apply after controlling for the family's socioeconomic status (Murray, 2012, 158).

Drawing on data from, inter alia, Aronson and Huston (2004) and Brown (2004), Murray advances a further overview of the effects of children born outside of a traditional marriage.

The differences begin in infancy, when most of the cohabiting couples are still living together and the child has a two-parent family. Stacey Aronson and Aletha Huston used data from a study of early child care conducted by the National Institute of Child Health and Human development to assess the mother-infant relationship and the home environment for children at ages 6 months and 15 months. On both measures and at both ages, the children of married couples did significantly better than the children of cohabiting parents, who in turn had scores that were only fractionally higher than the children of single mothers. . . . The disadvantages of being born to cohabiting parents extend into childhood and adolescence, even when the cohabiting couple still consists of the two biological parents. Susan Brown used the 1999 cohort for the National Survey of America's Families to examine behavioral and emotional problems and school engagement among six- to eleven-year-old children and twelve- to seventeen-year-old teens. Same story: Having two unmarried biological parents was 
associated with worse outcomes than having two married biological parents, and the outcomes were rarely better than those for children living with a single parent or in a 'cohabiting stepparent family' (Murray 2012, 164-165).

7. In 2001, annual health care expenditures were $\$ \$ 4.5$ billion, with $\$ \$ 28$ billion in the Medisave account (Lim, 2004, 86). By 2005, Medisave had risen to \$\$34.76 billion (Koh et al., 2008, 49). Further, by 2005, the assets of the Central Provident Fund amounted to $\$ \$ 120$ billion (Koh et al., 2008, 43).

8. The Singaporean affirmation of the traditional family is reflected in many parts of Singaporean culture and law. See in particular AAG v. Estate of $\mathrm{AAH}_{s}$ deceased (2009) SGCA 56, where the court held that an illegitimate child could not claim maintenance from the estate of a deceased parent. An editor of the Singapore Law Review, in commenting on this case, opined: "In some way, someone must suffer for someone else's gain. Denying the illegitimate child maintenance may be unfair, but to accord it to him may ironically be to visit upon the legitimate child the sins of his father!" (Junhui, 2010).

\section{REFERENCES}

Anzenbacher, A. 2002. "Geschlechterdifferenz und Familienpolitik." In Die Zukunft der Familie und deren Gefährdungen, edited by N. Goldschmidt, G. Beestermöller, and G. Steger, 223-40. Berlin, Germany: Lit Verlag.

Aronson, S. R., and A. C. Huston. 2004. The mother-infant relationship in single, cohabiting, and married families: A case for marriage? Journal of Family Psychology 18:5-18.

Baumgartner, A. 2003. "Familienautonomie und Familienförderung." In Die Zukunft der Familie und deren Gefährdungen, edited by N. Goldschmidt, G. Beestermöller, and G. Steger, 217-22. Berlin, Germany: Lit Verlag.

Blome, A. 2009. "Old and Young in the Welfare State - Lessons from International Comparisons." In Family and the Welfare State in Europe, edited by A. Blome, W. Keck, and J. Alber, 262-86. Cheltenham, United Kingdom: Edward Elgar.

Brown, S. L. 2004. Family structure and child well-being: The significance of parental cohabitation. Journal of Marriage and the Family 66:351-67.

Center on Budget and Policy Priorities. 2011. Policy basics: Where do our federal tax dollars go? (April 15) [On-line]. Available: http://www.cbpp.org/cms/index.cfm?fa=view\&id=1258 (Accessed August 8, 2012).

Cheah, J. 2010. Integrate now, create health: Perspectives from Singapore. International Journal of Integrated Care 10:1-2.

Cherry, M. 2011a. Familial authority and Christian bioethics - A geography of moral and social controversies. Christian Bioethics 17:185-205.

2011b. Sex, abortion and infanticide: The gulf between the secular and the divine. Christian Bioethics 17:25-46.

Daniels, N. 1981. Health care needs and distributive justice. Philosophy \& Public Affairs 10:146-79.

1985. Just Health Care. New York: Cambridge University Press.

1996. Justice and Justification. New York: Cambridge University Press.

2008. Just Health: Meeting Health Needs Fairly. New York: Cambridge University Press.

Daniels, N., and J. E. Sabin. 2002. Setting Limits Fairly. New York: Oxford University Press.

Department of Statistics Singapore. 2011. Statistics [On-line]. Available: http://www.singstat. gov.sg/stats/keyind.html\#mardiv (Accessed August 8, 2012).

Edin, K., and M. Kefalas. 2005. Promises I Can Keep: Why Poor Women Put Motherhood before Marriage. Berkeley: University of California Press. 
Eid, V. 1982. "Elemente einer theologisch-ethischen Lehre über die Familie." In Wandel der Familie - Zukunft der Familie, edited by V. Eid and L. Vaskovics, 179-200. Mainz, Germany: Matthias Grünewald Verlag.

Engelhardt, H. T., Jr. 1996. The Foundations of Bioethics. 2nd ed. New York: Oxford University Press.

- 2012. After equality: Some critical reflections on the financing of health care. Medicine E Philosophy [Yixue yu Zhexue; translated into Chinese] 33:1-5.

Fan, R. 1997. Self-determination vs. family determination: Two incommensurable principles of autonomy. Bioethics 11:309-22.

- 2010. Reconstructionist Confucianism. Dordrecht, the Netherlands: Springer.

-, ed. 2011. The Renaissance of Confucianism in Contemporary China. Dordrecht, the Netherlands: Springer.

Fukuyama, F. 2006. America at the Crossroads: Democracy, Power, and the Neoconservative Legacy. New Haven, CN: Yale University Press.

Grandits, H. 2010. "Introduction: The Reshaping of Family and Kin Relations in European Welfare Systems." In Family, Kinship and State in Contemporary Europe, vol. 1, edited by H. Grandits, 9-46. Frankfurt/M, Germany: Campus Verlag.

Green, R. 1976. "Health Care and Justice in Contract Theory Perspective." In Ethics and Health Policy, edited by R. Veatch and R. Branson, 111-26. Cambridge, MA: Ballinger.

Joshi, V. D., and J. F. Y. Lim. 2010. Health insurance in Singapore: Who's not included and why? Singapore Medical Journal 51:399-405.

Junhui, S. 2010. A father's sins. Singapore Law Review [On-line]. Available: http://www.singaporelawreview.org/2010/03/a-fathers-sins/ (Accessed August 9, 2012).

Koh, B. S. K., O. S. Mitchell, T. Tanuwidjaja, and J. Fong. 2008. Investment patterns in Singapore's Central Provident Fund system. Journal of Pension Economics and Finance 7:37-65.

Lim, M.-K. 2004. Shifting the burden of health care finance: A case study of public-private partnership in Singapore. Health Policy 69:83-92.

Martin, J. A., B. E. Hamilton, S. J. Ventura, M. J. K. Osterman, S. Kirmeyer, T. J. Mathews, and E. C. Wilson. 2011. Births: Final data for 2009. National Vital Statistics Reports 60:1-72.

Ministry of Health Singapore. 2012. Population and Vital Statistics [On-line]. Available: http://www.moh.gov.sg/content/moh_web/home/statistics/Health_Facts_Singapore/ Population_And_Vital_Statistics.html (Accessed August 8, 2012).

Moynihan, D. P. 1965. The Negro Family: A Case for National Action. Washington, DC: US Department of Labor.

Murray, C. 2012. Coming Apart: The State of White America, 1960-2010. New York: Crown Forum.

Overall, C. 2012. Why Have Children? Cambridge, MA: MIT Press.

Rawls, J. 1971. A Theory of Justice. Cambridge, MA: Belknap Press.

- 1985. Justice as fairness: Political not metaphysical. Philosophy and Public Affairs $14: 223-51$.

1993. Political Liberalism. New York: Columbia University Press.

. 1997. The idea of public reason revisited. The University of Chicago Law Review 64:765-807.

Rector, R. 2010. Marriage: America's greatest weapon against child poverty. Backgrounder 2465:1-16. 
Sanyal, S., S. Pettigrew, D. Ghista, O. B. Chi, and J. Lim. 2008. "Health Equity and Healthcare Equity - Eight Themes from an Island State." In Distributed Diagnosis and Home Healthcare, edited by R. Acharya, T. Tamura, E. Y. K. Ng, L. C. Min, and J. S. Suri, chapter 21. Valencia, CA: American Scientific Publishers.

Saw, S. H. 2005. Population Policies and Programmes in Singapore. Pasir Panjang, Singapore: Institute for Southeast Asian Studies.

Singapore Central Provident Fund. 2012. Annual report 2011 [On-line]. Available: http://mycpf. cpf.gov.sg/NR/rdonlyres/A0CDFD15-B815-4BD8-BC05-15D66F06E062/0/Overview.pdf (Accessed August 9, 2012).

Stern, L. 1983. Opportunity and health care: Criticisms and suggestions. Journal of Medicine and Philosophy 8:339-61.

Strosberg, M. A., J. M. Wiener, and R. Baker, eds. 1992. Rationing America's Medical Care: The Oregon Plan and beyond. Washington, DC: Brookings Institution.

Thévenon, O. 2010. Macro-level database on fertility and policies supporting families with children in European and OECD countries [On-line]. Available: http://www.oeaw.ac.at/ vid/repro/assets/docs/Databases.pdf (Accessed August 8, 2012).

Wilson, W. J. 1988. The Truly Disadvantaged: The Inner City, the Underclass, and Public Policy. Chicago: University of Chicago Press. 